\title{
Combination efficacy of pertuzumab and trastuzumab for trastuzumab emtansine-resistant cells exhibiting attenuated lysosomal trafficking or efflux pumps upregulation
}

\author{
Yoriko Yamashita-Kashima ${ }^{1}$ - Sei Shu ${ }^{1} \cdot$ Masahiro Osada ${ }^{1} \cdot$ Takaaki Fujimura $^{1} \cdot$ Shigeki Yoshiura $^{1} \cdot$ Naoki Harada $^{1}($ ) \\ Yasushi Yoshimura'
}

Received: 16 March 2020 / Accepted: 4 September 2020 / Published online: 30 September 2020

(c) The Author(s) 2020

\begin{abstract}
Purpose Trastuzumab emtansine (T-DM1) is the standard treatment in the current second-line therapy of human epidermal growth factor receptor 2 (HER2)-positive metastatic breast cancer. However, a useful therapy after T-DM1 resistance has not been established. In this study, we established two different HER2-positive T-DM1-resistant cancer cells and evaluated the antitumor effect of trastuzumab in combination with pertuzumab (TRAS + PER).

Methods Single-cell-cloned OE19 and BT-474 cells were cultured with increasing concentrations of T-DM1 to generate T-DM1-resistant OE19bTDR and BT-474bTDR cells, respectively. HER2 expression was assessed by immunohistochemistry. Multidrug resistance proteins (MDR1 and MRP1) were evaluated by real-time polymerase chain reaction and western blotting. Intracellular trafficking of T-DM1 was examined by flow cytometry and immunofluorescence staining. Efficacy of TRAS + PER was evaluated by cell proliferation assay, HER3 and AKT phosphorylation, caspase 3/7 activity, and antitumor activity.

Results HER2 expression of both resistant cells was equivalent to that of the parent cells. Overexpression of MDR1 and MRP1 was observed and affected the T-DM1 sensitivity in the OE19bTDR cells. Abnormal localization of T-DM1 into the lysosomes was observed in the BT-474bTDR cells. In BT-474bTDR cells, TRAS + PER inhibited the phosphorylation of AKT involved in HER2-HER3 signaling, and apoptosis induction and cell proliferation inhibition were significantly higher with TRAS + PER than with the individual drugs. TRAS + PER significantly suppressed tumor growth in the OE19bTDR xenograft model compared with each single agent.

Conclusions The results suggest that the TRAS + PER combination may be effective in T-DM1-resistant cancer cells where HER 2 overexpression is maintained.
\end{abstract}

Keywords Pertuzumab $\cdot$ Trastuzumab $\cdot$ Trastuzumab emtansine $\cdot$ T-DM1 resistance $\cdot$ HER2

\section{Abbreviations}

ABC ATP-binding cassette

ABCB1 ATP-binding cassette subfamily B member 1

ABCC1 ATP-binding cassette subfamily $\mathrm{C}$ member 1

ADCC Antibody-dependent cellular cytotoxicity

ATP Adenosine triphosphate

Electronic supplementary material The online version of this article (https://doi.org/10.1007/s00280-020-04138-5) contains supplementary material, which is available to authorized users.

Naoki Harada

haradanok@chugai-pharm.co.jp

1 Product Research Department, Chugai Pharmaceutical Co., Ltd., 200 Kajiwara, Kamakura, Kanagawa 247-8530, Japan
BCRP Breast cancer resistance protein

CAPE Capecitabine

CDC20 Cell-division cycle protein 20

CDK1 Cyclin-dependent kinase 1

EGFR Epidermal growth factor receptor

HER2 Human epidermal growth factor receptor 2

HRG $\beta \quad$ Heregulin $\beta$

HuIgG Human immunoglobulin $\mathrm{G}$

$\mathrm{IC}_{50} \quad$ Half maximal inhibitory concentration

IHC Immunohistochemistry

MDR1 Multidrug resistance protein 1

MOA Mechanism of action

mRNA Messenger RNA

MRP1 Multidrug resistance-associated protein 1

MUC4 Mucin 4 


$\begin{array}{ll}\text { PBS } & \text { Phosphate buffered saline } \\ \text { PCR } & \text { Polymerase chain reaction } \\ \text { PER } & \text { Pertuzumab } \\ \text { PTEN } & \text { Phosphatase and tensin homfolog } \\ \text { RT } & \text { Room temperature } \\ \text { siRNA } & \text { Small interfering RNA } \\ \text { SLC } & \text { Solute carrier } \\ \text { T-DM1 } & \text { Trastuzumab emtansine } \\ \text { TRAS } & \text { Trastuzumab }\end{array}$

\section{Introduction}

Trastuzumab emtansine (T-DM1) is composed of the human epidermal growth factor receptor 2 (HER2)-targeted humanized antibody trastuzumab (TRAS) and DM1, a maytansinoid derivative, linked with a non-reducible thioether linker, $\mathrm{N}$-succinimidyl-4-( $\mathrm{N}$-maleimidomethyl) cyclohexane-1-carboxylate (SMCC, designated MCC after conjugation). Upon binding to HER2 receptor, T-DM1 undergoes receptormediated internalization and subsequent lysosomal degradation, resulting in intracellular release of DM1-containing cytotoxic catabolites. Binding of DM1 to tubulin disrupts microtubule networks in cells, which results in cell cycle arrest and apoptotic cell death. In addition, T-DM1 has been reported to retain the mechanisms of action (MOAs) of TRAS [1-3].

TRAS is an anti-HER2 antibody that binds to domain IV of HER2; its antitumor MOAs include inhibition of ligandindependent HER2-HER3 signaling in HER2-amplified cells, antibody-dependent cellular cytotoxicity (ADCC), and inhibition of shedding of the extracellular domain of HER2 $[4,5]$. Pertuzumab (PER), another anti-HER2 antibody, binds to domain II of HER2 in HER2-positive breast cancer cells; its MOAs include inhibition of ligand-dependent HER2-HER3 signaling by blocking heterodimerization of HER2 with other HER family members (including epidermal growth factor receptor [EGFR], HER3, and HER4) and ADCC [6, 7]. TRAS and PER inhibit HER2 signals through different mechanisms, thereby producing a synergistic effect [7-9].

Treatment guidelines, such as those from the American Society of Clinical Oncology [10], National Comprehensive Cancer Network [11], and Japanese Breast Cancer Society [12], recommend that in patients with HER2-positive metastatic breast cancer, the standard first-line therapy should include the TRAS + PER + docetaxel combination and second-line therapy should include T-DM1. This recommendation is based on results showing significant improvement in progression-free survival and/or overall survival in the phase 3 CLEOPATRA (TRAS + PER + docetaxel vs
TRAS + docetaxel) $[13,14]$ and EMILIA (T-DM1 vs lapatinib + capecitabine [CAPE]) [15] studies.

As third-line therapy, the continuous use of a HER-targeting drug, such as TRAS or lapatinib, with chemotherapy has been reported to prolong progression-free survival in patients [16, 17]; however, data on the selection of antiHER2 drugs in patients with T-DM1 resistance are lacking and require clarification. Recently, several possible mechanisms of T-DM1 resistance have been reported: (1) reduced binding of T-DM1 to HER2 by HER2 downregulation [18] or by mucin 4 (MUC4) [19]; (2) attenuation of AKT signal inhibition caused by phosphatase and tensin homolog (PTEN) loss [20]; (3) signaling via the EGFR [21]; (4) overexpression of adenosine triphosphate (ATP)-binding cassette $(\mathrm{ABC})$ transporters that are involved in multidrug resistance $[18,20,22]$; (5) downregulation of the lysosomal transporter solute carrier family 46 member 2 (SLC46A2) [20, 23], lysosomal metabolic disorders [24, 25], or abnormal lysosomal trafficking [26]; or (6) altered microtubule dynamics through a mutation in tubulin or altered activation of mitotic regulators [27, 28]. Except for (1)-(3), these resistance mechanisms are specific to T-DM1 and not to TRAS or PER. Therefore, when HER 2 expression and downstream signaling are normal and the HER2-binding site is not masked, a possible modality is to re-administer TRAS + PER for complete blocking of HER2 signaling. Therefore, the objective of the current study was to evaluate the antitumor effect of the TRAS + PER combination in HER2-positive T-DM1resistant cell lines, thereby demonstrating the feasibility of re-administration of TRAS + PER after T-DM1 resistance has occurred in HER2-positive metastatic breast cancer.

\section{Materials and methods}

\section{Test agents}

T-DM1, TRAS, and PER were provided by Chugai Pharmaceutical Co., Ltd. Human immunoglobulin G (HuIgG) was purchased from MP Biomedicals, LLC. TRAS and $\mathrm{HuIgG}$ were dissolved in distilled water. All agents were diluted with saline for in vivo experiments and with culture medium for in vitro experiments. CAPE, obtained from Chugai Pharmaceutical Co., Ltd., was suspended in $40 \mathrm{mmol} / \mathrm{L}$ citrate buffer ( $\mathrm{pH}$ 6.0) containing 5\% gum Arabic as the vehicle. DM1- $\mathrm{CH}_{3}$ was purchased from Toronto Research Chemicals.

\section{Cell lines and culture conditions}

HER2-positive human gastroesophageal junction cancer cell line OE19 was obtained from the European Collection of Authenticated Cell Cultures (catalog no. 96071721) 
and maintained in RPMI-1640 (Sigma-Aldrich catalog no. R8758), supplemented with $10 \%$ fetal bovine serum (Bovogen Biologicals catalog no. SFBS-C; Sigma-Aldrich catalog no. 172012; or Nichirei Biosciences catalog no. 174012), $1 \mathrm{mM}$ sodium pyruvate, $10 \mathrm{mM}$ HEPES, and $0.45 \% \mathrm{D}-\mathrm{glu}-$ cose. HER2-positive human breast cancer cell line BT-474 was obtained from the American Type Culture Collection (catalog no. HTB-20) and maintained in RPMI-1640 supplemented with $10 \%$ fetal bovine serum, $1 \mathrm{mM}$ sodium pyruvate, $10 \mathrm{mM}$ HEPES, $0.45 \%$ D-glucose, and $10 \mu \mathrm{g} / \mathrm{mL}$ bovine insulin. Cell lines were cultured at $37{ }^{\circ} \mathrm{C}$ under $5 \%$ $\mathrm{CO}_{2}$.

\section{Establishment of resistant cell lines}

Single-cell cloning was performed on the OE19 and BT-474 cell lines to produce the OE19b and BT-474b cell lines, respectively. These were cultured with stepwise increase in concentrations of T-DM1 from 0.03 to $1.89 \mu \mathrm{g} / \mathrm{mL}$ and from 0.11 to $3.58 \mu \mathrm{g} / \mathrm{mL}$ for approximately 8 months to produce the T-DM1-resistant cell lines OE19bTDR and BT-474bTDR, respectively. OE19bTDR was maintained in culture medium with $1.89 \mu \mathrm{g} / \mathrm{mL}$ T-DM1, whereas BT-474bTDR was maintained in culture medium without T-DM1.

\section{In vitro antiproliferation assay}

Cells seeded on 96 -well plates at $1 \times 10^{4}$ cells/well and precultured for $24 \mathrm{~h}$ were treated with T-DM1 or DM1- $\mathrm{CH}_{3}$ and incubated for 3 or 4 days. For the antiproliferation assay of T-DM1 in the presence of multidrug resistance protein 1 (MDR1) or multidrug resistance-associated protein 1 (MRP1) inhibitor, verapamil or MK-571 was added simultaneously with T-DM1. The cell number was analyzed with the blue fluorescent Hoechst 33258 nucleic acid stain as previously described [29]. For the antiproliferation assay of T-DM1 after knockdown of MDR1 or MRP1, the proliferation was analyzed with Cell Proliferation ELISA, BrdU (colorimetric) (Roche Diagnostics). For the antiproliferation assay of TRAS + PER, cells were treated with $40 \mu \mathrm{g} / \mathrm{mL}$ of $\mathrm{HuIgG}$, TRAS, and/or PER, and with $20 \mathrm{ng} /$ $\mathrm{mL}$ of heregulin $\beta$ (HRG $\beta$ ) $24 \mathrm{~h}$ later, and then cultured for 6 days. Proliferation was analyzed with Cell Counting Kit-8 (Dojindo Laboratories). The percentage of cell proliferation was calculated as follows: $\%$ proliferation $=($ measured value of treatment well - measured value of precultured well)/ (measured value of non-treated well - measured value of precultured well $) \times 100$.

To estimate the half maximal inhibitory concentration $\left(\mathrm{IC}_{50}\right)$, the logarithmic-translated value of the drug concentration ( $x$ axis) and percentage of proliferation ( $y$ axis) were plotted and the two points across the $\mathrm{IC}_{50}$ value were fitted to a straight line. $\mathrm{IC}_{50}$ values were then estimated using the fitted line.

\section{HER2 protein expression (immunohistochemistry)}

Cells were suspended and solidified in iPGell (GenoStaff). These were fixed with $10 \%$ neutral buffered formalin for $24 \mathrm{~h}$ and embedded in paraffin. HER2 protein expression was examined by immunohistochemistry (IHC) using HercepTest (Dako) at SRL Medisearch. HER2 scoring was determined by SRL Medisearch in accordance with the guidelines for gastric or breast cancer.

\section{Exome sequencing}

Genomic DNA samples were extracted by a NucleoSpin Tissue Kit (Takara Bio). Next-generation sequencing was performed at Takara Bio. Sequencing library construction for human exome sequencing was done using Sure SelectXT Reagent Kit and Sure Select XT Human All Exon Kit V6 (Agilent Technologies). Sequencing was done using NovaSeq 6000 (Illumina).

\section{MDR1 and MRP1 mRNA expression}

The levels of messenger RNA (mRNA) expression of MDR1/ ATP-binding cassette subfamily B member 1 (ABCB1) and MRP1/ATP-binding cassette subfamily $\mathrm{C}$ member 1 (ABCC1) were determined using LightCycler 480 (Roche Diagnostics). Total RNA was extracted using RNeasy Mini Kit (Qiagen) and reverse transcribed using High-Capacity RNA-to-cDNA Kit (Thermo Fisher Scientific) and TaqMan probe/primer sets (ABCB1, Hs00184500_m1; ABCC1, Hs01561502_m1; Applied Biosystems).

\section{Western blotting}

Whole cells were lysed in a cell lysis buffer (Cell Signaling Technology), containing a protease inhibitor cocktail (Sigma-Aldrich) and phosphatase inhibitor cocktail (Nacalai Tesque), and these lysates were fractionated on sodium dodecyl sulfate-polyacrylamide gel electrophoresis and transferred to polyvinylidene fluoride membranes using the iBlot 2 Dry Blotting System (Thermo Fisher Scientific) or were used for the capillary electrophoresis-based protein analysis system Sally Sue (ProteinSimple).

For the analysis of HER2-HER3 signal inhibition, cells were treated with $\mathrm{HuIgG}$ (as a control), TRAS $(40 \mu \mathrm{g} / \mathrm{mL})$, PER $(40 \mu \mathrm{g} / \mathrm{mL})$, or both for $3.5 \mathrm{~h}$ in serum-free medium and stimulated with $100 \mathrm{ng} / \mathrm{mL}$ of HRG $\beta$ for $5 \mathrm{~min}$. Thereafter, cells were lysed as described above. 
Primary antibodies against MDR1, HER2, pHER2, HER3, pHER3, AKT, PTEN, cell-division cycle protein 20 (CDC20), Aurora A, Aurora B, MAD2L1, cyclin B1, pAKT, $\beta$-actin (Cell Signaling Technology), MRP1, solute carrier family 46 member 3 (SLC46A3), BubR1, and cyclindependent kinase 1 (CDK1) (Abcam) were used.

\section{MDR efflux assay}

Cells seeded on 96 -well plates at $4 \times 10^{4}$ cells/well and precultured for $24 \mathrm{~h}$ were treated with 2,4 , or $8 \mu \mathrm{M}$ of verapamil or 5,10 , or $25 \mu \mathrm{M}$ of MK-571, and incubated for $2.5 \mathrm{~h}$. MDR pump efflux activity was then detected using an MDR Assay Kit (Abcam).

\section{Knockdown of MDR1 or MRP1}

Cells seeded on six-well plates at $4 \times 10^{5}$ cells/well and precultured for $24 \mathrm{~h}$ were transfected with ON-TARGETplus Human ABCB1 (5243) small interfering RNA (siRNA)SMARTpool, ON-TARGETplus Human ABCC1 (4363) siRNA-SMARTpool, or ON-TARGETplus Non-targeting siRNA \#4 (Dharmacon) using Lipofectamine RNAiMAX (Thermo Fisher Scientific). Following incubation and retransfection, the cells were used for the antiproliferation assay of T-DM1.

\section{Assessment of mitotic spindle formation}

Cells seeded on eight-well chamber slides at $3 \times 10^{4}$ cells/ well and precultured for $48 \mathrm{~h}$ were treated with T-DM1 and incubated for $48 \mathrm{~h}$. The cells were washed and fixed with $4 \%$ paraformaldehyde for $10 \mathrm{~min}$ at room temperature (RT). The cells were then washed and permeabilized with $0.2 \%$ Triton X-100/phosphate buffered saline (PBS) for $15 \mathrm{~min}$ at RT. Thereafter, the cells were washed and blocked with blocking buffer (3\% bovine serum albumin in PBS) for $1 \mathrm{~h}$ at RT. Primary antibody (anti-alpha tubulin antibody [Abcam]) and secondary antibody (anti-rabbit $\operatorname{IgG}[\mathrm{H}+\mathrm{L}]$, $\mathrm{F}\left[\mathrm{ab}{ }^{\prime}\right]_{2}$ fragment [Alexa Fluor 555 Conjugate] [Cell Signaling Technology]) were added and incubated for $1 \mathrm{~h}$ at RT, respectively. After removing from the chamber, one drop of ProLong Gold Antifade Mountant with DAPI (Thermo Fisher Scientific) was added and a cover glass was placed. Fluorescence microscopy (Nikon, C1Si Confocal Microscope) at $60 \times$ magnification was used to visualize the cells.

\section{Detection of T-DM1 on the cell surface}

Cells seeded on six-well plates at $1 \times 10^{6}$ cells and precultured were treated with $5 \mu \mathrm{g} / \mathrm{mL}$ of T-DM1 or HuIgG and incubated at $4{ }^{\circ} \mathrm{C}$ for $1 \mathrm{~h}$. After changing the medium, cells were incubated at $37^{\circ} \mathrm{C}$ for $0,24,48$, or $72 \mathrm{~h}$. The cells were collected and treated with PE Mouse Anti-Human IgG (BD Biosciences) and then incubated at $4{ }^{\circ} \mathrm{C}$ for $40 \mathrm{~min}$. The samples were analyzed on the flow cytometer using FlowJo 10.4.1 (BD Biosciences).

\section{Assessment of intracellular T-DM1}

Cells were seeded on 24-well plates with collagen1-coated cover glasses at $2.5 \times 10^{5}$ cells and precultured. The cells were treated with Alexa-488-labeled T-DM1 or IgG (labeled using Zenon Alexa Fluor 488 Human IgG Labeling Kit [Thermo Fisher Scientific]) and incubated for 5 or $24 \mathrm{~h}$. After washes, the cells were fixed with $4 \%$ paraformaldehyde for $15 \mathrm{~min}$ at $37^{\circ} \mathrm{C}$. The mountant used was ProLong Diamond Antifade Mountant (Thermo Fisher Scientific). Fluorescence microscopy at $60 \times$ magnification was used to visualize the cells.

\section{Assessment of the localization of T-DM1 to lysosome}

For the detection of T-DM1 transported to the lysosome, cells were seeded on 96-well black polystyrene microplate clear flat bottom (Corning) and precultured. T-DM1 or HuIgG was labeled with pHAb Amine Reactive Dyes (Promega). Cells were treated with T-DM1 or HuIgG-pHAb for $1 \mathrm{~h}$ at $4{ }^{\circ} \mathrm{C}$ and for $24 \mathrm{~h}$ at $37^{\circ} \mathrm{C}$. After incubation, the medium was exchanged with PBS and cells were visualized with fluorescence microscopy.

\section{Apoptosis assay}

Cells were seeded on 96-well white-wall plates at $1 \times 10^{4}$ cells/well and precultured for $24 \mathrm{~h}$. The medium was changed to serum-free medium and cells were additionally precultured for $24 \mathrm{~h}$. The cells were treated with $40 \mu \mathrm{g} / \mathrm{mL}$ of $\mathrm{HuIgG}$, TRAS, and/or PER, and half an hour later, with $40 \mathrm{ng} / \mathrm{mL}$ of HRG $\beta$, and then incubated for $24 \mathrm{~h}$. Caspase 3/7 activity was assessed using the Caspase-Glo 3/7 Assay (Promega).

\section{Xenograft model}

All animal experiments were performed in accordance with the Guidelines for the Care and Use of Laboratory Animals at Chugai Pharmaceutical Co., Ltd., and all animal procedures were reviewed and approved by the Institutional Animal Care and Use Committee at Chugai Pharmaceutical Co., Ltd. (approval number: 15-362). Five to seven-weekold male BALB/c-nu/nu mice (CAnN.Cg-Foxn $1^{n u} / \mathrm{CrlCrlj}$, purchased from Charles River Laboratories Japan) were inoculated subcutaneously in the right flank with $5 \times 10^{6}$ cells/mouse with either OE19b or OE19bTDR cells. Several weeks after the inoculation, mice were randomized to 
the control group or treatment groups. T-DM1 $(10 \mathrm{mg} / \mathrm{kg})$ or saline was administered intravenously once every 3 weeks. TRAS (40 or $80 \mathrm{mg} / \mathrm{kg}$ ) and/or PER (40 or $80 \mathrm{mg} / \mathrm{kg}$ ), or $\mathrm{HuIgG}$ was administered intraperitoneally once a week for 3 weeks. CAPE $(359 \mathrm{mg} / \mathrm{kg}$ ) or vehicle was administered orally for the initial 14 days. Tumor volume and body weight were measured twice a week. Tumor volume was calculated as described previously [8].

\section{Statistical analyses}

The Dunnett test was used to compare the means from multiple experimental groups with those of the control group. The Student's $t$ test was used to compare means of two different experimental groups. The Tukey-Kramer's test was used for pairwise comparison of means between multiple groups. The Wilcoxon test was used to compare in vivo samples, and for multiple comparisons, hierarchical testing and Bonferroni correction were applied. $P$ values $<0.05$ or $<0.025$ with Bonferroni correction were considered statistically significant, and the analysis was performed using JMP 11.2.1 (SAS Institute Japan Ltd.).

\section{Results}

\section{Establishment and characterization of T-DM1-resistant cell lines}

Single-cell cloning was performed on the OE19 and BT-474 cell lines and the OE19b and BT-474b cell lines were established, respectively. The proliferation rate, HER 2 expression, and sensitivity to T-DM1 of these cell lines were confirmed to be comparable with those of OE19 or BT-474. Furthermore, these were cultured in increasing concentrations of T-DM1 to produce the resistant cell lines OE19bTDR and BT-474bTDR, respectively. To characterize the two established T-DM1-resistant cell lines, sensitivity to T-DM1 and HER2 expression was assessed. The $\mathrm{IC}_{50}$ value of T-DM1 was approximately 900-fold in the OE19bTDR cells ( $34 \mu \mathrm{g} /$ $\mathrm{mL})$ than in the OE $19 \mathrm{~b}$ cells $(0.036 \mu \mathrm{g} / \mathrm{mL})$. The corresponding $\mathrm{IC}_{50}$ value of T-DM1 was approximately 40 -fold in the BT-474bTDR cells $(3.6 \mu \mathrm{g} / \mathrm{mL})$ than in the BT- $474 \mathrm{~b}$ cells $(0.098 \mu \mathrm{g} / \mathrm{mL}$ ) (Fig. 1a, b). A positive HER2 expression represented by complete circumferential and strong membrane staining of more than $10 \%$ of cells (IHC score $3+$ ) was observed in both the resistant cell lines (Fig. 1c, d) (consistent with findings in Ref. [20, 21] for BT-474). HER2 downstream signaling in OE19bTDR and BT-474bTDR was also equivalent to that in the parental cells (Fig. 1e). We also assessed ERBB2, ERBB3, PIK3CA, PIK3R1, PTEN, $A K T 1, P D K 1$ mutations, but there were no differences in functional mutations between parental and resistant cells (data not shown).

\section{Resistance to DM1-CH $\mathrm{CH}_{3}$ and expression of multidrug resistance proteins}

Furthermore, we examined whether T-DM1 resistance was due to the resistance of the payload DM1. The sensitivity to DM1- $\mathrm{CH}_{3}$, which is the methyl form of DM1, was assessed in the established T-DM1-resistant cell lines because thiol-containing compounds, such as DM1, can form a disulfide-mediated dimer or a mixed disulfide with other thiol-containing substituents in the cell culture medium or intracellularly and are, therefore, not stable [3].

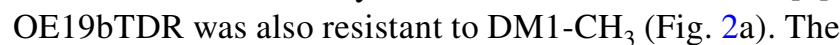
cell cycle arrest after T-DM1 treatment was also examined because DM1- $\mathrm{CH}_{3}$ induced the inhibition of tubulin polymerization. Flow cytometry showed T-DM1-induced $M$ phase arrest (G2/M) in the OE19b cells ( $70 \%$ of cells), whereas M phase arrest was suppressed in the OE19bTDR cells (24\% of cells) (Online Resource 1a). The gene mutations and expression levels of mitosis-related proteins were not different between resistant and parental cells (data not shown and Online Resource $1 \mathrm{~b}$ ). Sensitivity to DM1- $\mathrm{CH}_{3}$ was similar between the BT-474bTDR and the BT-474b cells (Fig. 2b), which is consistent with the results of a previous study [20]. Using real-time polymerase chain reaction (PCR), an increase in relative mRNA expression of MDR1 and MRP1 was observed in the OE19bTDR cells compared with the OE19b cells (Fig. 2c), which was confirmed by western blotting (Fig. 2e); no increase in relative mRNA expression was observed in the BT-474bTDR cells compared with BT-474b cells (Fig. 2d).

\section{Involvement of MDR1 and MRP1 expression in the T-DM1 resistance of OE19bTDR}

To assess the activities of the MDR1 and MRP1 expressed on OE19b or OE19bTDR cells, the efflux activity of the fluorescent dye molecule, which was the substrate of MDR1 and MRP1, was determined. The intensity of cellular fluorescence was remarkably lower in the OE19bTDR cells than in the OE19b cells. A significant dose-dependent recovery of cellular fluorescence in the OE19bTDR cells was demonstrated with increasing concentrations of the MDR1 inhibitor verapamil and MRP1 inhibitor MK-571 (Fig. 3a). Consequently, proliferation assays demonstrated significant recovery of T-DM1 sensitivity in the OE19bTDR cells in the presence of verapamil and MK-571 (Fig. 3b). Furthermore, significant recovery of 
a

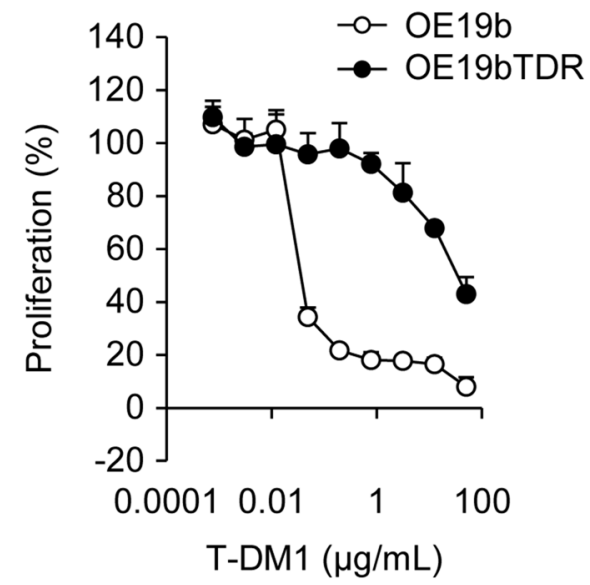

C

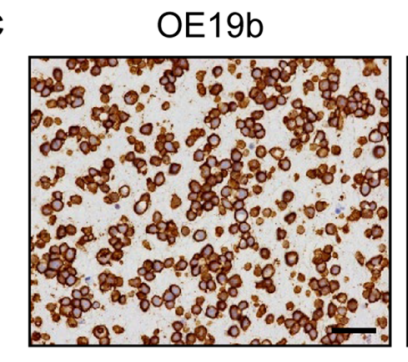

d

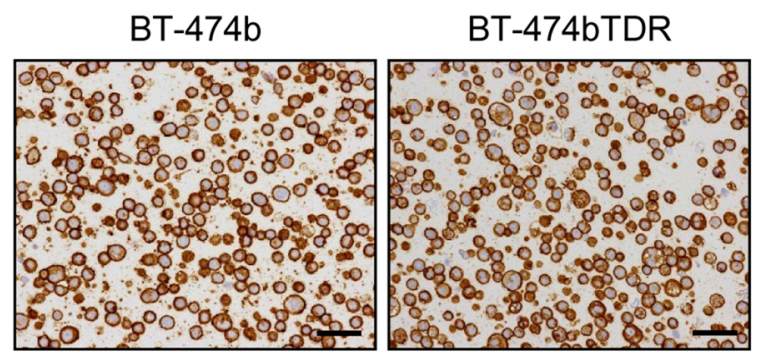

b

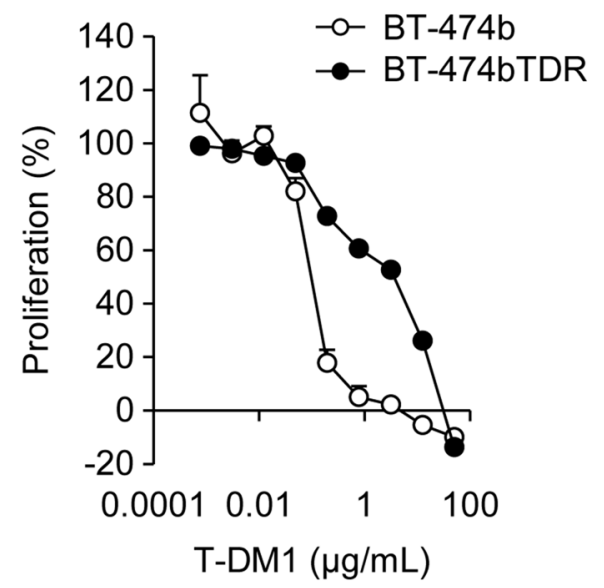

e
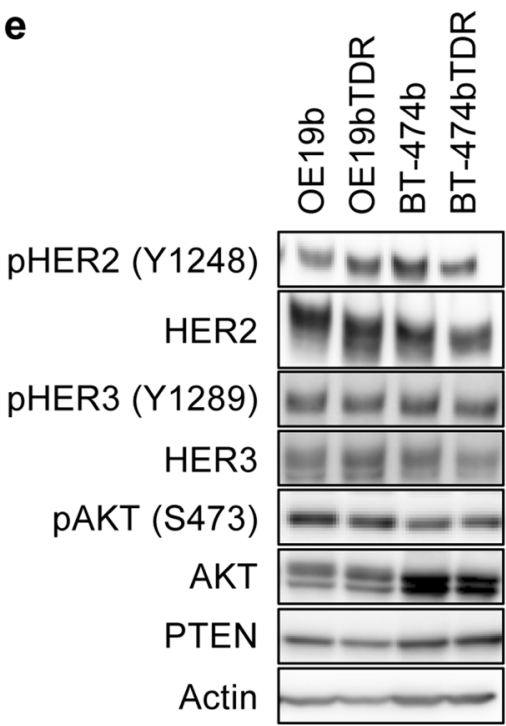

Fig. 1 Characterization of the two T-DM1-resistant cell lines. Cell growth inhibition by T-DM1 was examined 4 days after treatment in the OE19b, OE19bTDR, a BT-474b, and BT-474bTDR cells. b Data points are mean $+\mathrm{SD}(n=3)$. HER2 expression in the T-DM1-resist- ant cell lines was detected by immunohistochemistry. Black line represents $50 \mu \mathrm{m}(\mathbf{c}, \mathbf{d})$. HER2-HER3-AKT signaling was detected by western blotting (e) sensitivity to T-DM1 was demonstrated in the OE19bTDR cells after the knockdown of MDRI or MRPI gene expression by siRNA (Fig. 3c).

\section{Intracellular uptake of T-DM1}

In the BT-474bTDR cells, no increase in expression of MDR1 or MRP1 was observed, and the sensitivity of DM1$\mathrm{CH}_{3}$ was similar to that of the parent cells (Fig. 2b, d). However, staining of tubulin showed that mitotic spindles were not inhibited at concentrations of T-DM1 up to $5 \mu \mathrm{g} / \mathrm{mL}$ in the BT-474bTDR cells compared with concentrations up to $0.5 \mu \mathrm{g} / \mathrm{mL}$ in the BT- $474 \mathrm{~b}$ cells (Fig. $4 \mathrm{a}$ ). Thus, we examined the process during which receptor-bound T-DM1 was endocytosed into the cell, recruited to lysosome, degraded to DM1 in lysosome, and DM1 released from lysosome to cytosol for inhibiting mitotic spindle formation. The T-DM1 on the cell surface and intracellular uptake of T-DM1 in the BT474bTDR cells were similar to those in the BT-474b cells (Fig. 4b, c), indicating that endocytosis of receptor-bound T-DM1 was not inhibited in BT-474bTDR cells. For the detection of T-DM1 transported to the lysosome, we used pHAb Amine Reactive Dyes, which fluoresced only in the acidic compartments in cells, for example, in lysosomes $(\mathrm{pH}$ 5.0). Lysosomal localization of T-DM1 decreased in the BT474bTDR cells (Fig. 4d). Despite this decrease, cathepsin activity in lysosome did not decrease in the BT-474bTDR cells (Online Resource 2a). In addition, the expression of 
a

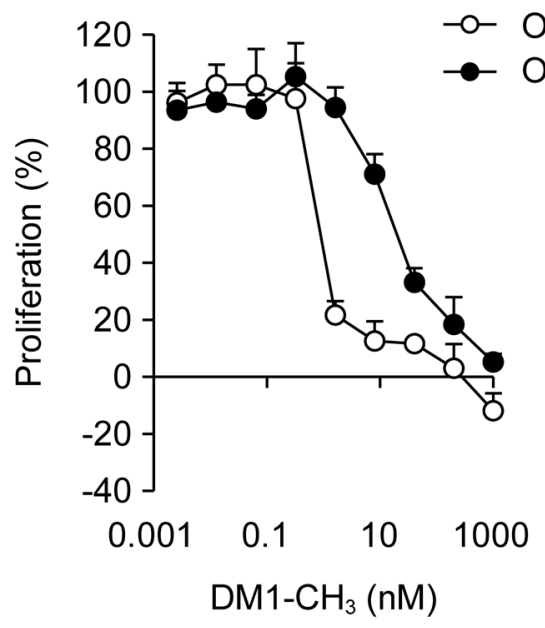

C
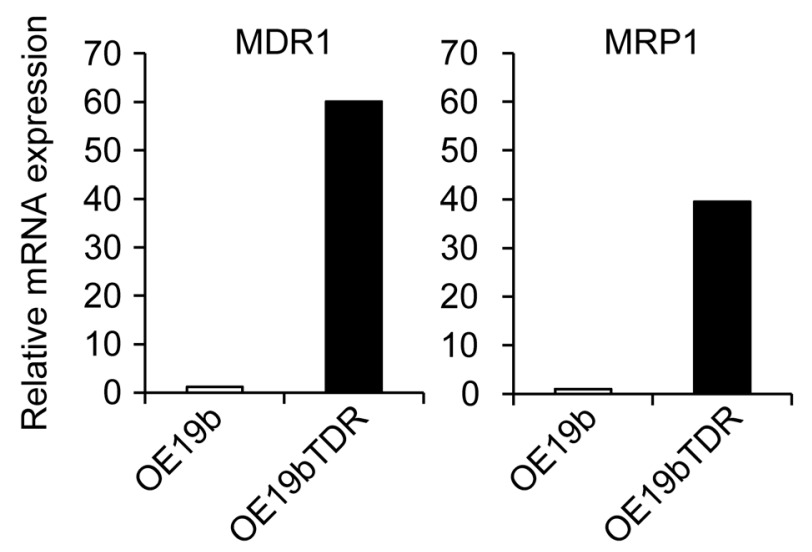

e
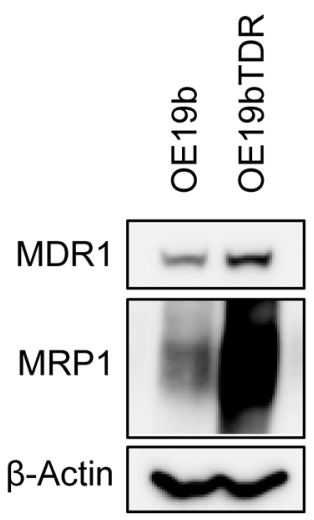

Fig. 2 Sensitivity to $\mathrm{DM} 1-\mathrm{CH}_{3}$ and expression of multidrug-resistant proteins in the two T-DM1-resistant cell lines. Cell growth inhibition by DM1- $\mathrm{CH}_{3}$ was examined 3 days after treatment in $\mathrm{OE} 19 \mathrm{~b}$ and OE19bTDR (a), and in BT-474b and BT-474bTDR (b). Data points are mean $+\mathrm{SD}(n=3)$. Relative mRNA expression (mean, $n=2)$ of

SLC46A3 (lysosomal transporter of DM1-based catabolites) was comparable to that of the BT-474b cells (Online Resource $2 b$ ). These results indicated that recruiting of b

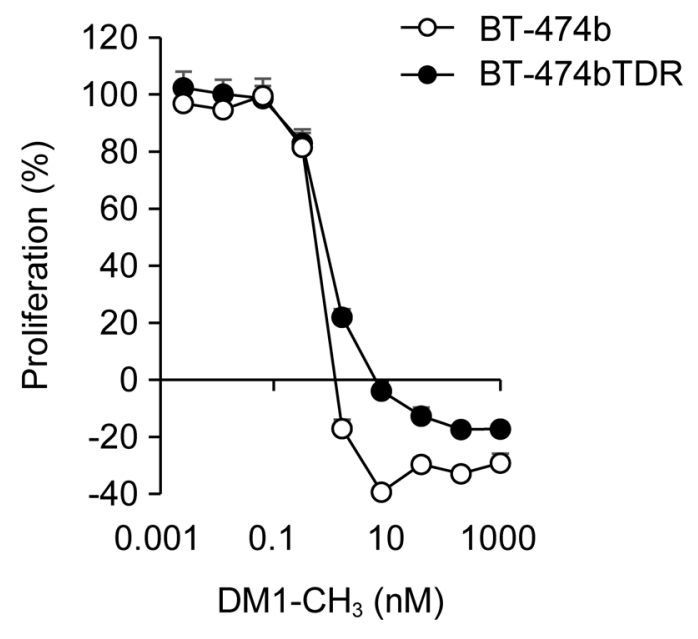

d
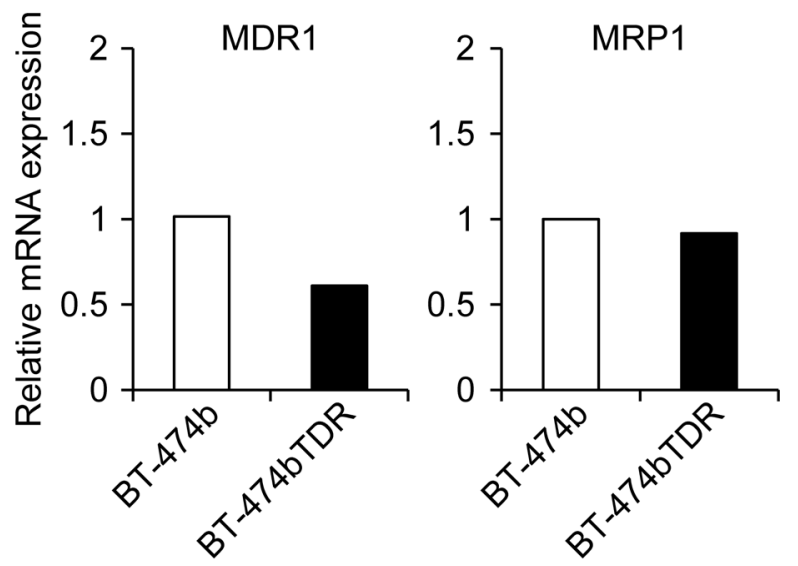

MDR1 and MRP1 in OE19bTDR cells vs OE19b cells (c) and in BT474bTDR cells vs BT-474b cells (d) was measured by quantitative real-time PCR. (e) Expression of MDR1 and MRP1 in OE19bTDR vs OE19b cells

T-DM1 to lysosome after endocytosis was inhibited in the BT-474bTDR cells rather than degradation of T-DM1 in lysosome and release of DM1 from lysosome to cytosol. 
a

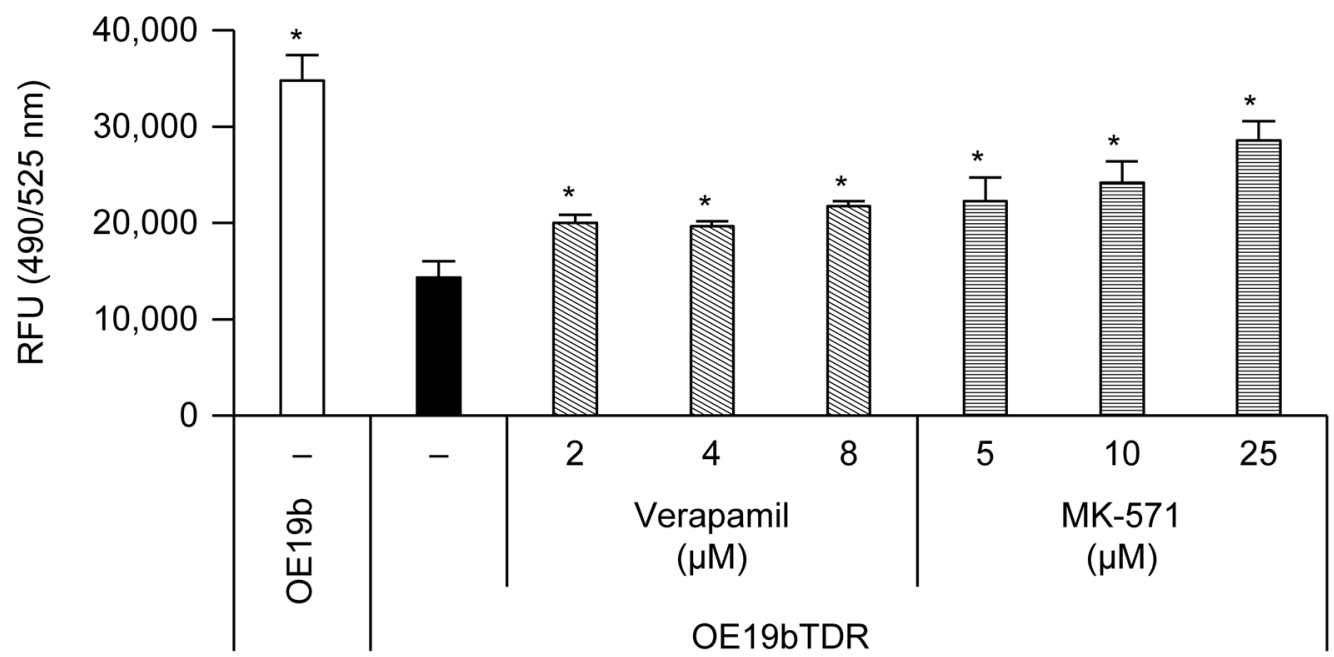

b

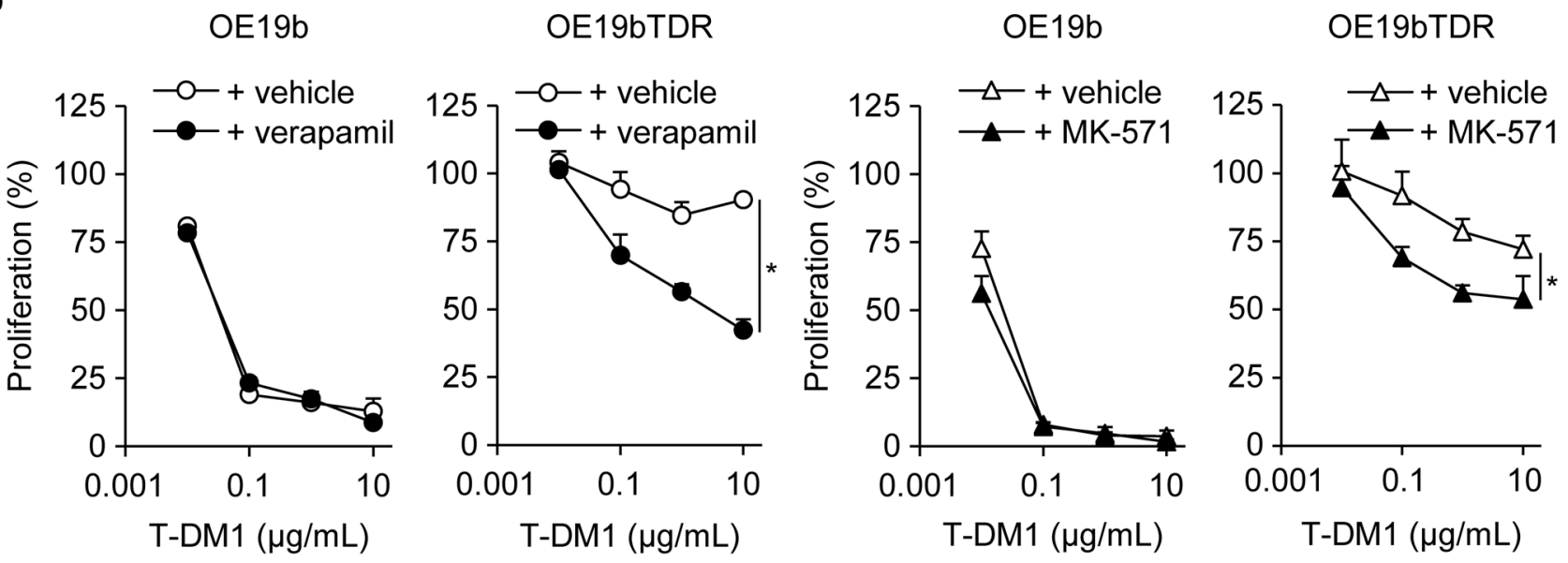

C
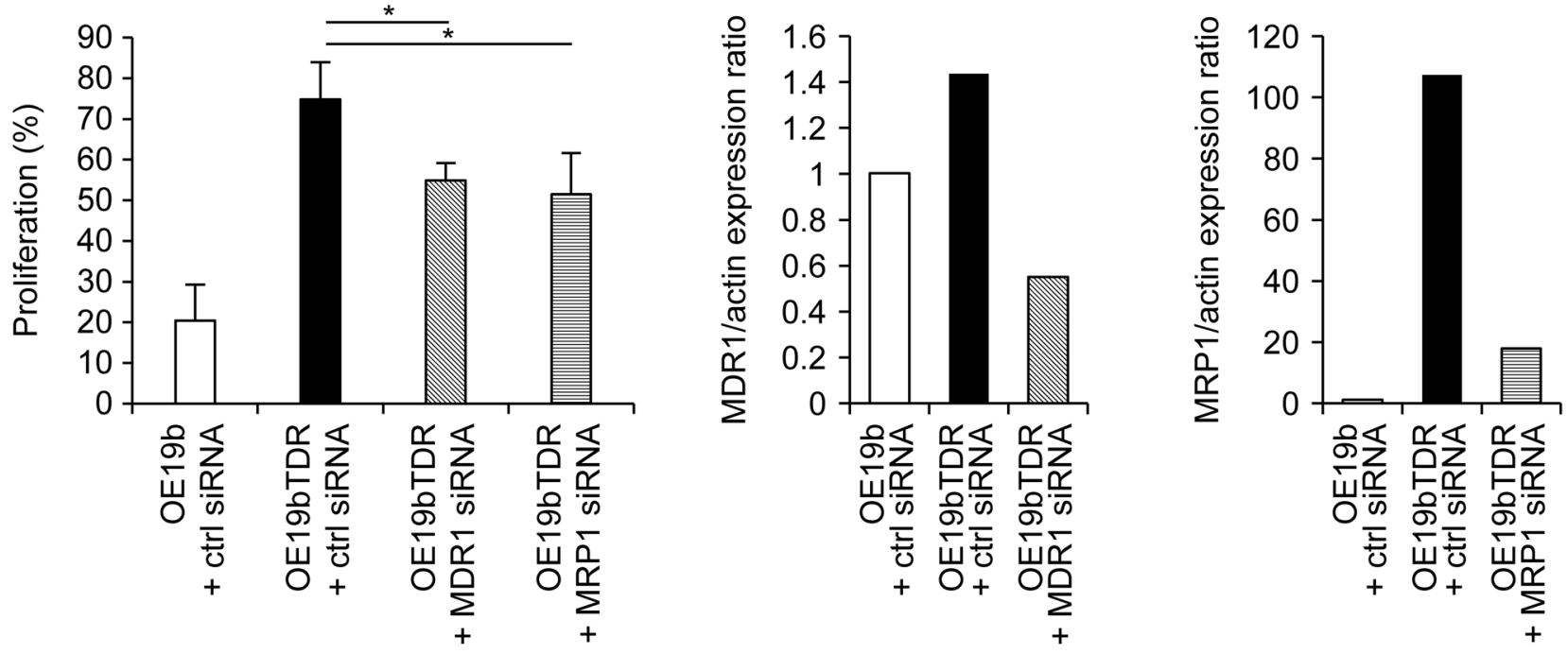
4Fig. 3 Involvement of MDR1 and MRP1 in the T-DM1 resistance of OE19bTDR cells. a Cells were incubated with indicated concentrations of verapamil or MK-571 for $2.5 \mathrm{~h}$ and dye efflux by MDRs was measured. Data points are mean $+\mathrm{SD}(n=3) \quad(* P<0.05$ for all doses; Dunnett test). b, c Cell growth inhibition by T-DM1 was examined 3 days after treatment in the presence of verapamil $(8 \mu \mathrm{M})$ or MK-571 $(20 \mu \mathrm{M}), \mathbf{b}$ or under the condition of MDR1 or MRP1 knockdown. c Cells were treated with T-DM1 at $0.5 \mu \mathrm{g} / \mathrm{mL}$, and the proliferation rate was calculated as the ratio of the proliferation of cells transfected with control siRNAs to the proliferation of cells treated with $0 \mu \mathrm{g} / \mathrm{mL}$ of T-DM1. Data points are mean $+\mathrm{SD}(n=3)$ $\left({ }^{*} P<0.05\right.$; Student's $t$ test). MDR1 and MRP1 expression levels were detected by western blotting, and the expression rate compared with that of the parent cell was calculated by a ratio with actin

\section{Efficacy of the TRAS + PER combination in T-DM1- resistant cell lines}

Because HER2 overexpression was maintained in the BT474bTDR cells (Fig. 1d), the dependence on HER2-HER3 heterodimer signaling was examined. The phosphorylation of HER3 and AKT was similarly inhibited by TRAS + PER treatment in the BT-474b and BT-474bTDR cells (Fig. 5a). Relative caspase 3/7 activity in the BT-474bTDR vs BT-474b cells showed significant induction of apoptosis at $24 \mathrm{~h}$ after treatment with PER alone and TRAS + PER compared with controls; apoptosis induction was significantly higher with TRAS + PER than with the individual drugs (Fig. 5b). As a result, a significant reduction in cell proliferation was also observed in the BT-474bTDR vs BT-474b cells at day 7 with PER alone and TRAS + PER compared with controls; inhibition was significantly higher with TRAS + PER than with the individual drugs (Fig. 5c).

The OE19bTDR xenografted tumors were also resistant to T-DM1 treatment compared with the OE19b tumors (Fig. 6a). Because of the lower sensitivity of OE19b to TRAS or PER in the xenograft model, mice with OE19b and OE19bTDR tumors were treated with a higher dose. Tumor growth was significantly suppressed with the TRAS + PER combination compared with TRAS and PER alone (tumor growth inhibition rates on day 22 were $19 \%$ with TRAS, $18 \%$ with PER, and $58 \%$ with TRAS + PER in the OE19bTDR xenograft model) (Fig. 6b).

In the combination treatment with CAPE, a chemotherapeutic agent used as the third-line drug in combination with anti-HER2 therapy, the OE19bTDR tumors were sensitive to CAPE and CAPE + TRAS treatment. Furthermore, the addition of PER to the CAPE + TRAS combination led to a significant decrease in tumor volume in the OE19bTDR xenograft model (Fig. 6c).

\section{Discussion}

The molecular mechanisms that drive clinical resistance to T-DM1, especially in HER2-positive tumors, are not well understood. In the OE19bTDR cells, suppression of MDR1 or MRP1 by each inhibitor or siRNA partially restored the cytotoxic activities of T-DM1, and result from RNA sequence analysis showed no increase in other ABC transporters, including ABCB2 or ABCG2 (data not shown), indicating that expression of MDRs was predominantly associated with T-DM1 resistance. Previous studies have also reported on the overexpression of $\mathrm{ABC}$ transporters as resistant mechanisms of T-DM1. Le Joncour et al. reported that upregulation of $\mathrm{ABCC} 1 / \mathrm{MRP} 1$ and ABCC2/MRP2 caused T-DM1 resistance in the OE19 cell line and $\mathrm{ABCC} 2$ and $\mathrm{ABCG} 2 /$ breast cancer resistance protein (BCRP) in the NCI-N87 cell line [22]. Sauveur et al. reported alterations to cell adhesion molecules using the OE19 cell line [30]. Loganzo et al. reported that overexpression of ABCC1-induced T-DM1 resistance in 361 cell lines [18], and Li et al. reported that ABCB1 overexpression and HER 2 downregulation were causes of T-DM1 resistance in KPL-4 cells [20]. Thus, overexpression of ABC transporters may inherently contribute to T-DM1 resistance and could be one of the representative characters of T-DM1 resistance.

In BT-474bTDR cells, T-DM1 uptake from the cell membrane to cytosol followed by trafficking to endosome was not impaired. However, the amount of T-DM1 in the lysosome was decreased, and neither a loss of lysosome enzyme activity nor a loss of the lysosomal transporter SLC46A3 was observed. These results suggested that the mechanism of T-DM1 resistance in BT-474bTDR could be decreased localization of T-DM1 into the lysosomes without loss of lysosomal activity. Rios-Luci et al. reported that impaired lysosomal proteolytic activity is one of the T-DM1 resistant mechanisms [24], whereas $\mathrm{Li}$ $\mathrm{G}$ et al. reported loss of lysosomal transporter SLC46A3 and PTEN deficiency in BT-474M1 cells [20]. Kinneer et al. reported SLC46A3 loss in SK-BR-3 cells [31], and Wang et al. reported lysosome acidification decrease (vacuolar $\mathrm{H}+-\mathrm{ATPase}$ decrease) in NCI-N87 cells [25]. Thus, although several mechanisms could exist, deficiency of DM1 release from lysosome may be another representative resistance mechanism, and $\mathrm{BT}-474 \mathrm{bTDR}$ would have an equivalent resistance mechanism to this class.

The trafficking abnormality of T-DM1 to lysosomes due to endocytosis by caveolin-1 is implicated in T-DM1 
a
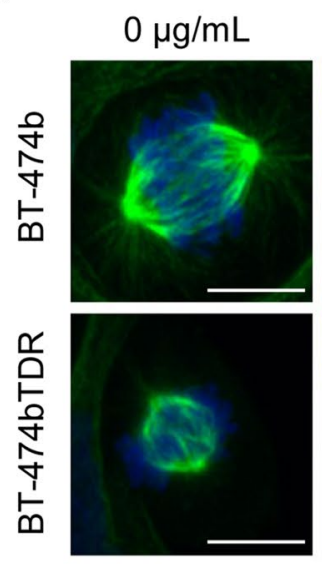

C
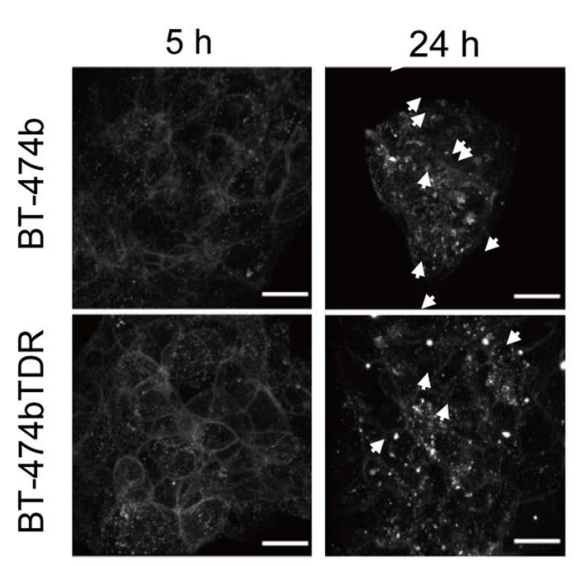

$0.5 \mu \mathrm{g} / \mathrm{mL}$
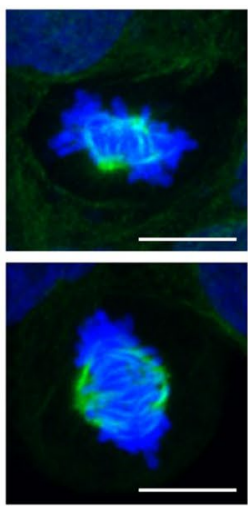

b
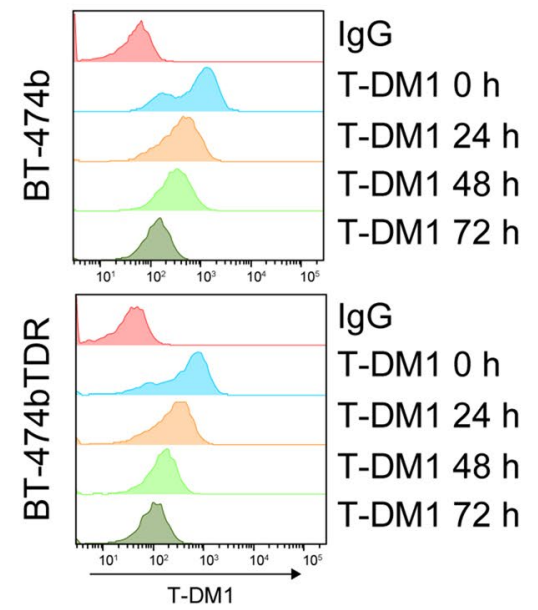

d
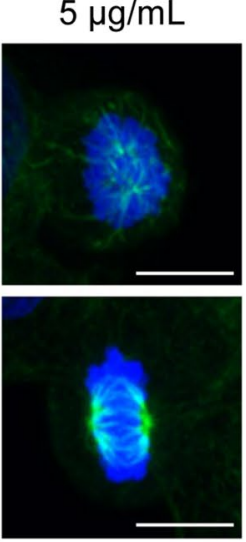

T-DM1-pHAb
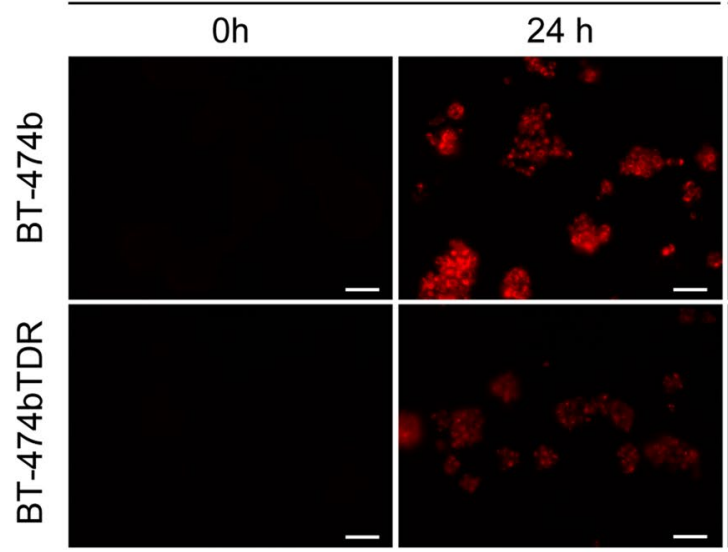

HulgG-pHAb

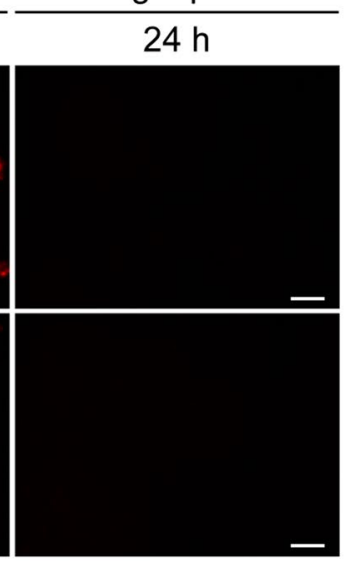

Fig. 4 Intracellular uptake of T-DM1 in BT-474b and BT-474bTDR cells. a Mitotic spindle formation in T-DM1-treated cells. Cells were treated with T-DM1 for $48 \mathrm{~h}$ and tubulin was detected by immunofluorescence staining (green: anti-tubulin antibody; blue: DAPI). White line represents $10 \mu \mathrm{m}$. b Cell surface T-DM1 was detected by flow cytometry at $0,24,48$, and $72 \mathrm{~h}$ after T-DM1 addition. c Alexa488-labeled T-DM1 was incubated with cells and detected after $24 \mathrm{~h}$

resistance [26]. Although caveolin-1 is responsible for the internalization of HER 2 molecule and affects TRAS efficacy [32], its overexpression was not observed in BT474bTDR cells (data not shown). Further studies are necessary to elucidate the mechanism of resistance in BT474bTDR cells. Despite the trafficking abnormality of membrane-bound molecules, HER 2 expression level was maintained and HER2 signal inhibition was effective in BT-474bTDR. Therefore, in cancers that maintain HER2 overexpression after T-DM1 resistance similar to that in the BT-474bTDR cells, signal inhibitors such as TRAS and PER, other than antibody-drug conjugates, might be a reasonable treatment. incubation using fluorescence microscopy (white arrow: T-DM1). White line represents $20 \mu \mathrm{m}$. d Lysosomal localization of T-DM1. Cells were incubated with $\mathrm{pHAb}$ thiol reactive dye-labeled T-DM1 (T-DM1-pHAb) or HuIgG (HuIgG-pHAb) for $24 \mathrm{~h}$ and visualized with fluorescence microscopy. White line represents $100 \mu \mathrm{m}$. The figures show a typical dyeing image of multiple experiment results (a, c, and d)

It is recognized that among the different known MOAs, the combination of TRAS + PER induces inhibition of both ligand-dependent and ligand-independent HER2-HER3 signaling [5, 33]. In this study, the combination of TRAS + PER induced the inhibition of phosphorylation of downstream factors involved in HER2-HER3 heterodimer signaling, and apoptosis induction and reduction in cell proliferation were significantly higher with the TRAS + PER combination than with the individual drugs in the BT-474bTDR and BT-474b cells. Furthermore, tumor growth was significantly suppressed with the TRAS + PER combination in the OE19bTDR xenograft model compared with either TRAS or PER alone. 


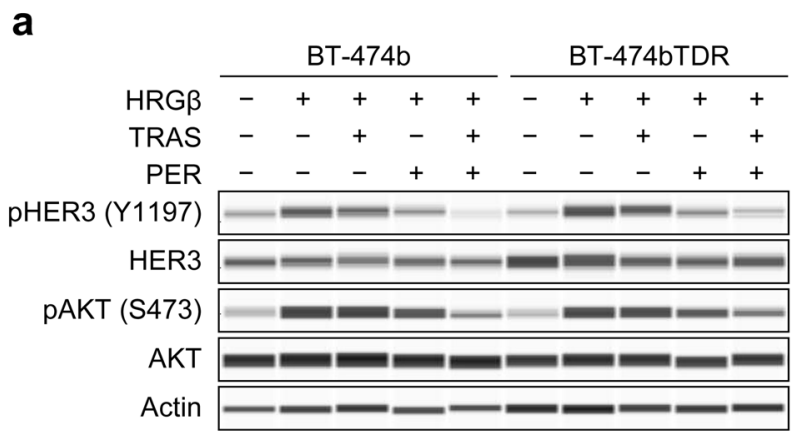

b

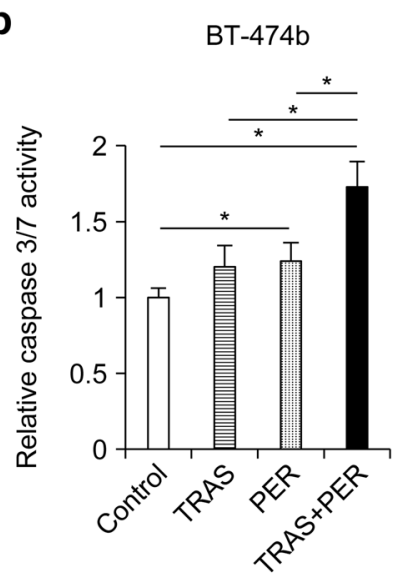

C

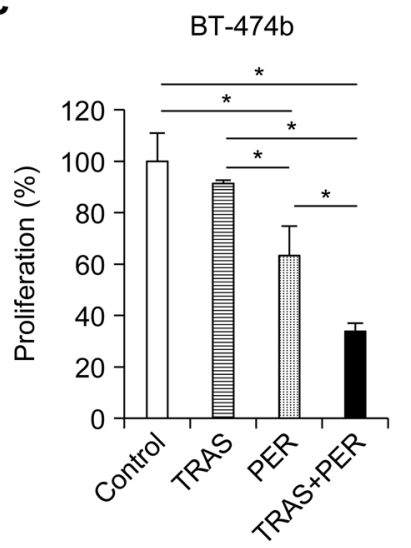

BT-474bTDR
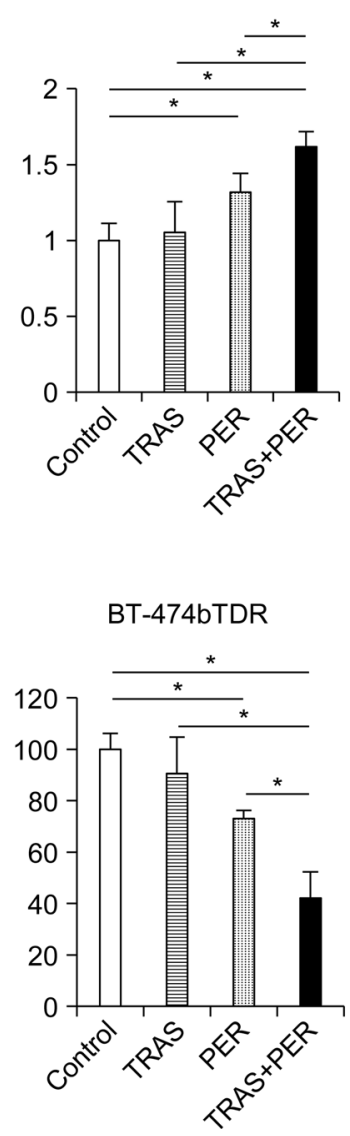

Fig. 5 Sensitivity of TRAS + PER in BT-474b and BT-474bTDR cells. a Indicated cells were treated with TRAS and PER $(40 \mu \mathrm{g} / \mathrm{mL}$ each) for $3.5 \mathrm{~h}$ and then incubated with HRG $\beta(100 \mathrm{ng} / \mathrm{mL})$ for $5 \mathrm{~min}$. Phosphorylation of HER3 and AKT was detected by western blotting. b Cells were treated with TRAS and/or PER $(40 \mu \mathrm{g} / \mathrm{mL}$ each), and half an hour later, with $40 \mathrm{ng} / \mathrm{mL}$ of $\mathrm{HRG} \beta$, and then incubated for $24 \mathrm{~h}$. Caspase 3/7 activity was measured using the Caspase-Glo Assay kit. Data plots are mean $+\mathrm{SD}(n=5 /$ group; $* P<0.05$ for all comparisons; Tukey-Kramer's test). c Cells were treated with TRAS and/or PER (40 $\mu \mathrm{g} / \mathrm{mL}$ each) for $24 \mathrm{~h}$, then incubated with HRG $\beta$ $(20 \mathrm{ng} / \mathrm{mL})$, and then treated for 6 days. Cell growth inhibition was examined by Cell Counting Kit-8. Data plots are mean $+\mathrm{SD}(n=3 /$ group; $* P<0.05$ for all comparisons; Tukey-Kramer's test)

In clinical practice, TRAS or TRAS + PER is used in combination with other chemotherapy drugs [10-12]. In case the T-DM1-resistant tumor has sensitivity to chemotherapeutic drugs, it is likely that PER and TRAS in combination with chemotherapy will be more effective. Therefore, we explored the antitumor activity of CAPE, TRAS, and PER. We observed that the OE19bTDR xenografted tumors were sensitive to CAPE and CAPE + TRAS and that the triple combination of CAPE + TRAS + PER showed significant antitumor effect compared with CAPE + TRAS in the xenograft model, although PER alone did not show antitumor activity (Fig. 6b, c). This suggests that TRAS + PER in combination with chemotherapy such as CAPE may be useful for T-DM1-resistant cancers caused by overexpression of MDR1 and MRP1 by proper selection of chemotherapy drugs.

Although our present study has some limitations, because the T-DM1-resistant cells in this study were established from cells naïve for both TRAS and PER despite the clinical use of T-DM1 after the regimen including TRAS and PER, our results showed the potential of TRAS + PER + chemotherapy as third-line combination therapy after T-DM1 resistance if cancer cells remain dependent on HER2.

The clinical application of our findings is being evaluated in an ongoing multicenter, randomized, open-label, phase 3 study (PRECIOUS trial). This clinical study aims to demonstrate the usefulness of PER re-administration after resistance to T-DM1 in HER2-positive locally advanced/ metastatic breast cancer patients with a history of PER administration. This study is based on the premise that if HER2-HER3 signaling, which was suppressed by previously used PER-containing regimens, is restored during antiHER2 therapy without PER, such as T-DM1 therapy before re-administration of a PER-containing regimen, PER readministration might potentially re-suppress HER2-HER3 signaling [34]. If the efficacy of PER re-administration is demonstrated in the PRECIOUS trial, then PER re-administration may become the standard third- and subsequentline therapy for HER2-positive locally advanced/metastatic breast cancer.

\section{Conclusion}

The results of this study suggest that the combination of TRAS + PER may be effective in T-DM1-resistant cancer where HER2 overexpression is maintained. 
a

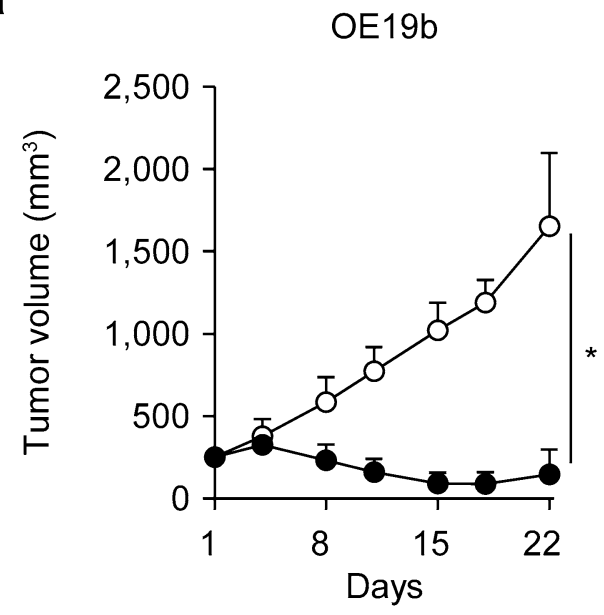

b

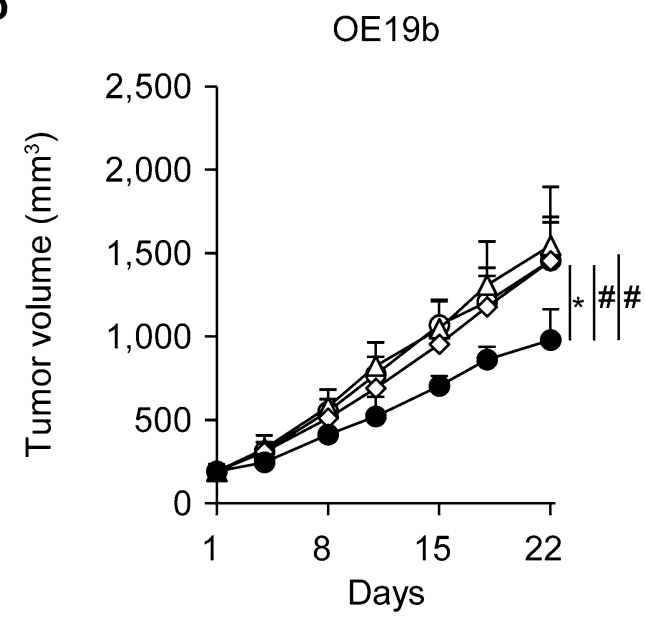

OE19bTDR

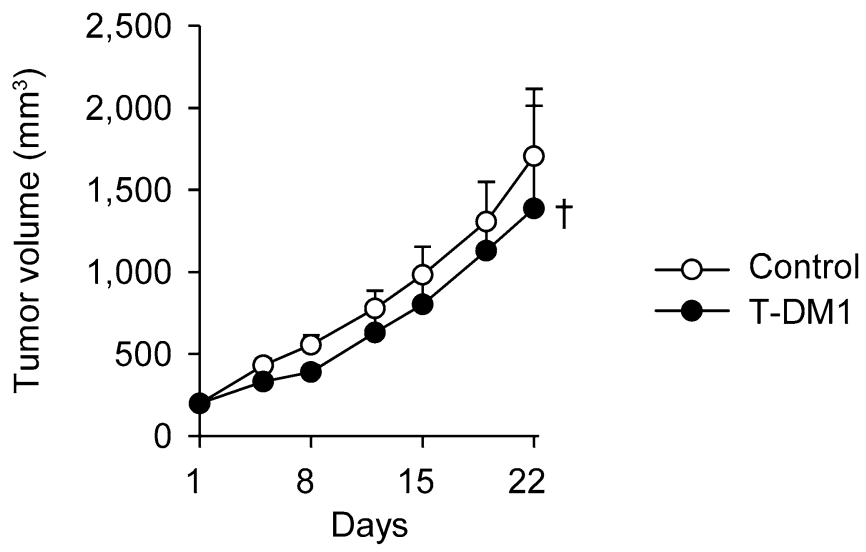

OE19bTDR

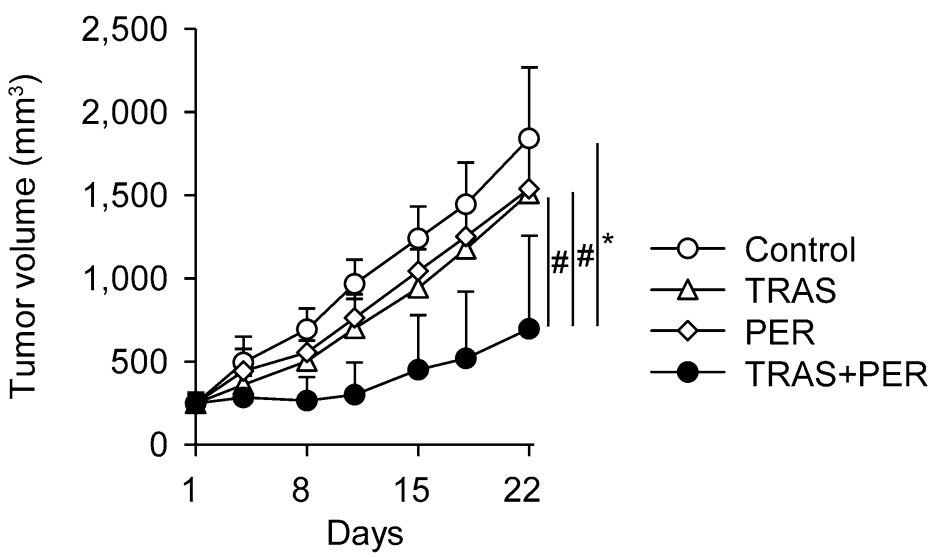

C

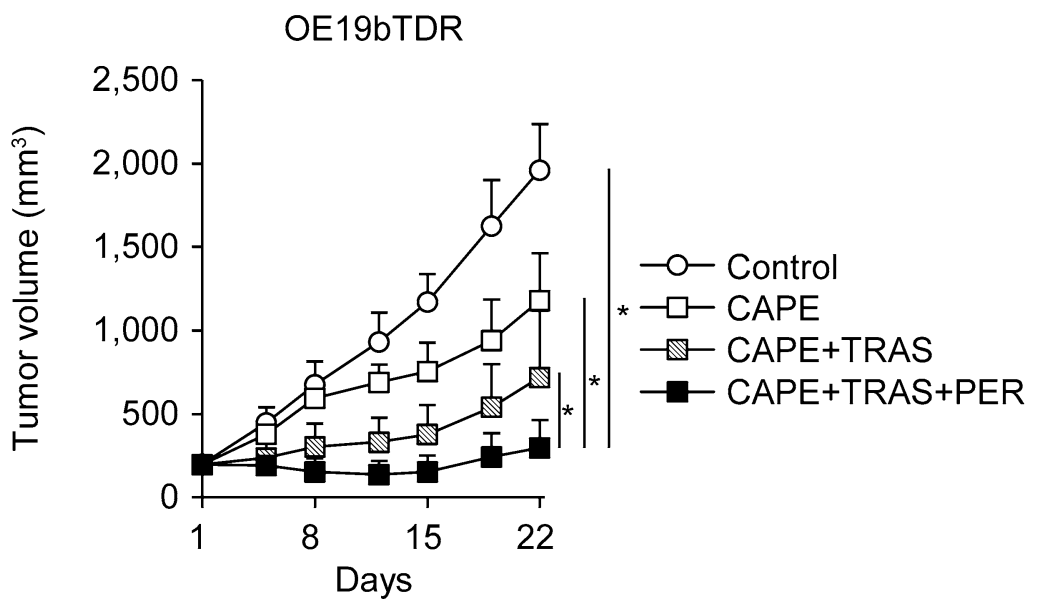


4Fig. 6 Antitumor activity of the TRAS + PER combination in a T-DM1-resistant cancer xenograft model. a Mice bearing OE19b or OE19bTDR tumors were randomly divided into two groups $(n=6 /$ group) and treated with saline or T-DM1 $(10 \mathrm{mg} / \mathrm{kg}$ intravenously once every 3 weeks $\left({ }^{*} P<0.05\right.$; Wilcoxon test). ${ }^{\dagger}$ One mouse was euthanized, because the tumor volume exceeded the ethical standard of the Institutional Animal Care and Use Committee at Chugai Pharmaceuticals, Co., Ltd. b The mice were randomly divided into four groups ( $n=6 /$ group) and treated with $\mathrm{HuIgG}$, TRAS, PER, or TRAS + PER $(80 \mathrm{mg} / \mathrm{kg}$ each $)$ intraperitoneally once a week for 3 weeks $\left(* P<0.05,{ }^{\#} P<0.025\right.$; Wilcoxon test with Bonferroni correction). c OE19bTDR xenografted mice were randomly divided into four groups ( $n=6 /$ group) and treated with HuIgG, CAPE, CAPE + TRAS, or CAPE + TRAS + PER. TRAS, PER, or HuIgG was administered intraperitoneally at $40 \mathrm{mg} / \mathrm{kg}$ once a week for 3 weeks; CAPE $(359 \mathrm{mg} / \mathrm{kg})$ or CAPE vehicle was administered perorally for initial 14 days $(* P<0.05$; Wilcoxon test)

Acknowledgements We appreciate the contributions of Dr. Kaori Ouchi-Fujimoto and Dr. Kazushige Mori (Product Research Department, Chugai Pharmaceutical Co., Ltd.) for helpful discussions and suggestions, and Marie Mochizuki and Mirei Kouno (Product Research Department, Chugai Pharmaceutical Co., Ltd.) for technical assistance in this study. Third-party assistance under the direction of the authors was provided by Annirudha Chillar, MD, PhD, of Cactus Life Sciences (part of Cactus Communications).

\section{Compliance with ethical standards}

Conflict of interest All authors are employees of Chugai Pharmaceutical Co., Ltd.

Ethical approval The experiments in this study comply with the current laws of the country in which they were performed. This article does not contain any evaluations on human participants. All procedures performed in studies involving animals were in accordance with the ethical standards of the institution or practice at which the studies were conducted (the Institutional Animal Care and Use Committee at Chugai Pharmaceutical, Co., Ltd., No. 15-362).

Open Access This article is licensed under a Creative Commons Attribution 4.0 International License, which permits use, sharing, adaptation, distribution and reproduction in any medium or format, as long as you give appropriate credit to the original author(s) and the source, provide a link to the Creative Commons licence, and indicate if changes were made. The images or other third party material in this article are included in the article's Creative Commons licence, unless indicated otherwise in a credit line to the material. If material is not included in the article's Creative Commons licence and your intended use is not permitted by statutory regulation or exceeds the permitted use, you will need to obtain permission directly from the copyright holder. To view a copy of this licence, visit http://creativecommons.org/licenses/by/4.0/.

\section{References}

1. Lewis Phillips GD, Li G, Dugger DL, Crocker LM, Parsons KL, Mai E, Blättler WA, Lambert JM, Chari RV, Lutz RJ, Wong WL, Jacobson FS, Koeppen H, Schwall RH, Kenkare-Mitra SR, Spencer SD, Sliwkowski MX (2008) Targeting HER2-positive breast cancer with trastuzumab-DM1, an antibody-cytotoxic drug conjugate. Cancer Res 68:9280-9290
2. Erickson HK, Lewis Phillips GD, Leipold DD, Provenzano CA, Mai E, Johnson HA, Gunter B, Audette CA, Gupta M, Pinkas J, Tibbitts J (2012) The effect of different linkers on target cell catabolism and pharmacokinetics/pharmacodynamics of trastuzumab maytansinoid conjugates. Mol Cancer Ther 11:1133-1142

3. Junttila TT, Li G, Parsons K, Phillips GL, Sliwkowski MX (2011) Trastuzumab-DM1 (T-DM1) retains all the mechanisms of action of trastuzumab and efficiently inhibits growth of lapatinib insensitive breast cancer. Breast Cancer Res Treat 128:347-356

4. Sliwkowski MX, Lofgren JA, Lewis GD, Hotaling TE, Fendly BM, Fox JA (1999) Nonclinical studies addressing the mechanism of action of trastuzumab (Herceptin). Semin Oncol 26(4 Suppl 12):60-70

5. Junttila TT, Akita RW, Parsons K, Fields C, Lewis Phillips GD, Friedman LS, Sampath D, Sliwkowski MX (2009) Ligand-independent HER2/HER3/PI3K complex is disrupted by trastuzumab and is effectively inhibited by the PI3K inhibitor GDC-0941. Cancer Cell 15:429-440

6. Agus DB, Akita RW, Fox WD, Lewis GD, Higgins B, Pisacane PI, Lofgren JA, Tindell C, Evans DP, Maiese K, Scher HI, Sliwkowski MX (2002) Targeting ligand-activated ErbB2 signaling inhibits breast and prostate tumor growth. Cancer Cell 2:127-137

7. Scheuer W, Friess T, Burtscher H, Bossenmaier B, Endl J, Hasmann M (2009) Strongly enhanced antitumor activity of trastuzumab and pertuzumab combination treatment on HER2-positive human xenograft tumor models. Cancer Res 69:9330-9336

8. Yamashita-Kashima Y, Shu S, Yorozu K, Moriya Y, Harada N (2017) Mode of action of pertuzumab in combination with trastuzumab plus docetaxel therapy in a HER2-positive breast cancer xenograft model. Oncol Lett 14:4197-4205

9. Yamashita-Kashima Y, Iijima S, Yorozu K, Furugaki K, Kurasawa M, Ohta M, Fujimoto-Ouchi K (2011) Pertuzumab in combination with trastuzumab shows significantly enhanced antitumor activity in HER2-positive human gastric cancer xenograft models. Clin Cancer Res 17:5060-5070

10. Giordano SH, Temin S, Chandarlapaty S, Crews JR, Esteva FJ, Kirshner JJ, Krop IE, Levinson J, Lin NU, Modi S, Patt DA, Perlmutter J, Ramakrishna N, Winer EP, Davidson NE (2018) Systemic therapy for patients with advanced human epidermal growth factor receptor 2-positive breast cancer: ASCO Clinical Practice Guideline update. J Clin Oncol 36:2736-2740

11. National Comprehensive Cancer Network NCCN Guidelines. https://www.nccn.org/store/login/login.aspx?ReturnURL=https ://www.nccn.org/professionals/physician_gls/pdf/breast.pdf. Accessed 12 Feb 2020

12. Japanese Breast Cancer Society Clinical Practice Guideline for treatment of breast cancer, 2018 edition [available in Japanese]. https://jbcs.gr.jp/guidline/2018/. Accessed 12 Feb 2020

13. Baselga J, Cortés J, Kim SB, Im SA, Hegg R, Im YH, Roman L, Pedrini JL, Pienkowski T, Knott A, Clark E, Benyunes MC, Ross G, Swain SM, CLEOPATRA Study Group (2012) Pertuzumab plus trastuzumab plus docetaxel for metastatic breast cancer. N Engl J Med 366:109-119

14. Swain SM, Kim SB, Cortés J, Ro J, Semiglazov V, Campone M, Ciruelos E, Ferrero JM, Schneeweiss A, Knott A, Clark E, Ross G, Benyunes MC, Baselga J (2013) Pertuzumab, trastuzumab, and docetaxel for HER2-positive metastatic breast cancer (CLEOPATRA study): overall survival results from a randomised, double-blind, placebo-controlled, phase 3 study. Lancet Oncol 14:461-471

15. Diéras V, Miles D, Verma S, Pegram M, Welslau M, Baselga J, Krop IE, Blackwell K, Hoersch S, Xu J, Green M, Gianni L (2017) Trastuzumab emtansine versus capecitabine plus lapatinib in patients with previously treated HER2-positive advanced breast cancer (EMILIA): a descriptive analysis of final overall 
survival results from a randomised, open-label, phase 3 trial. Lancet Oncol 18:732-742

16. von Minckwitz G, du Bois A, Schmidt M, Maass N, Cufer T, de Jongh FE, Maartense E, Zielinski C, Kaufmann M, Bauer W, Baumann KH, Clemens MR, Duerr R, Uleer C, Andersson M, Stein RC, Nekljudova V, Loibl S (2009) Trastuzumab beyond progression in human epidermal growth factor receptor 2-positive advanced breast cancer: a German Breast Group 26/Breast International Group 03-05 Study. J Clin Oncol 27:1999-2006

17. von Minckwitz G, Schwedler K, Schmidt M, Barinoff J, Mundhenke C, Cufer T, Maartense E, de Jongh FE, Baumann KH, Bischoff J, Harbeck N, Lück H-J, Maass N, Zielinski C, Andersson M, Stein RC, Nekljudova V, Loibl S, GBG 26/BIG 03-05 study group and participating investigators (2011) Trastuzumab beyond progression: overall survival analysis of the GBG 26/ BIG 3-05 phase III study in HER2-positive breast cancer. Eur J Cancer 47:2273-2281

18. Loganzo F, Tan X, Sung M, Jin G, Myers JS, Melamud E, Wang F, Diesl V, Follettie MT, Musto S, Lam MH, Hu W, Charati MB, Khandke K, Kim KS, Cinque M, Lucas J, Graziani E, Maderna A, O’Donnell CJ, Arndt KT, Gerber HP (2015) Tumor cells chronically treated with a trastuzumab-maytansinoid antibodydrug conjugate develop varied resistance mechanisms but respond to alternate treatments. Mol Cancer Ther 14:952-963

19. Mercogliano MF, Martino MD, Venturutti L, Rivas MA, Proietti CJ, Inurrigarro G, Frahm I, Allemand DH, Deza EG, Ares S, Gercovich FG, Guzmán P, Roa JC, Elizalde PV, Schillaci R (2017) $\mathrm{TNF} \alpha$-induced mucin 4 expression elicits trastuzumab resistance in HER2-positive breast cancer. Clin Cancer Res 23:636-648

20. Li G, Guo J, Shen BQ, Yadav DB, Sliwkowski MX, Crocker LM, Lacap JA, Phillips GDL (2018) Mechanisms of acquired resistance to trastuzumab emtansine in breast cancer cells. Mol Cancer Ther 17:1441-1453

21. Endo Y, Shen Y, Youssef LA, Mohan N, Wu WJ (2018) T-DM1resistant cells gain high invasive activity via EGFR and integrin cooperated pathways. MAbs 10:1003-1017

22. Le Joncour V, Martins A, Puhka M, Isola J, Salmikangas M, Laakkonen P, Joensuu H, Barok M (2019) A novel anti-HER2 antibody-drug conjugate XMT-1522 for HER2-positive breast and gastric cancers resistant to trastuzumab emtansine. Mol Cancer Ther 18:1721-1730

23. Hamblett KJ, Jacob AP, Gurgel JL, Tometsko ME, Rock BM, Patel SK, Milburn RR, Siu S, Ragan SP, Rock DA, Borths CJ, O'Neill JW, Chang WS, Weidner MF, Bio MM, Quon KC, Fanslow WC (2015) SLC46A3 is required to transport catabolites of noncleavable antibody maytansine conjugates from the lysosome to the cytoplasm. Cancer Res 75:5329-5340

24. Ríos-Luci C, García-Alonso S, Díaz-Rodríguez E, Nadal-Serrano M, Arribas J, Ocaña A, Pandiella A (2017) Resistance to the antibody-drug conjugate T-DM1 is based in a reduction in lysosomal proteolytic activity. Cancer Res 77:4639-4651

25. Wang H, Wang W, Xu Y, Yang Y, Chen X, Quan H, Lou L (2017) Aberrant intracellular metabolism of T-DM1 confers T-DM1 resistance in human epidermal growth factor receptor 2-positive gastric cancer cells. Cancer Sci 108:1458-1468
26. Sung M, Tan X, Lu B, Golas J, Hosselet C, Wang F, Tylaska L, King L, Zhou D, Dushin R, Myers JS, Rosfjord E, Lucas J, Gerber HP, Loganzo F (2018) Caveolae-mediated endocytosis as a novel mechanism of resistance to trastuzumab emtansine (T-DM1). Mol Cancer Ther 17:243-253

27. Sabbaghi MA, Gil-Gómez G, Guardia C, Servitja S, Arpí O, García-Alonso S, Menendez S, Arumi-Uria M, Serrano L, Salido M, Muntasell A, Martínez-García M, Zazo S, Chamizo C, González-Alonso P, Madoz-Gúrpide J, Eroles P, Arribas J, Tusquets I, Lluch A, Pandiella A, Rojo F, Rovira A, Albanell J (2017) Defective cyclin B1 induction in trastuzumab-emtansine (T-DM1) acquired resistance in HER2-positive breast cancer. Clin Cancer Res 23:7006-7019

28. Saatci Ö, Borgoni S, Akbulut Ö, Durmuş S, Raza U, Eyüpoğlu E, Alkan C, Akyol A, Kütük Ö, Wiemann S, Şahin Ö (2018) Targeting PLK1 overcomes T-DM1 resistance via CDK1-dependent phosphorylation and inactivation of Bcl-2/xL in HER2-positive breast cancer. Oncogene 37:2251-2269

29. Yamashita-Kashima Y, Yoshimura Y, Fujimura T, Shu S, Yanagisawa M, Yorozu K, Furugaki K, Higuchi R, Shoda J, Harada N (2019) Molecular targeting of HER2-overexpressing biliary tract cancer cells with trastuzumab emtansine, an antibody-cytotoxic drug conjugate. Cancer Chemother Pharmacol 83:659-671

30. Sauveur J, Matera EL, Chettab K, Valet P, Guitton J, Savina A, Dumontet C (2018) Esophageal cancer cells resistant to T-DM1 display alterations in cell adhesion and the prostaglandin pathway. Oncotarget 9:21141-21155

31. Kinneer K, Meekin J, Tiberghien AC, Tai YT, Phipps S, Kiefer CM, Rebelatto MC, Dimasi N, Moriarty A, Papadopoulos KP, Sridhar S, Gregson SJ, Wick MJ, Masterson L, Anderson KC, Herbst R, Howard PW, Tice DA (2018) SLC46A3 as a potential predictive biomarker for antibody-drug conjugates bearing noncleavable linked maytansinoid and pyrrolobenzodiazepine warheads. Clin Cancer Res 24:6570-6582

32. Pereira PMR, Sharma SK, Carter LM, Edwards KJ, Pourat J, Ragupathi A, Janjigian YY, Durack JC, Lewis JS (2018) Caveolin-1 mediates cellular distribution of HER2 and affects trastuzumab binding and therapeutic efficacy. Nat Commun 9:5137

33. Pedersen MW, Jacobsen HJ, Koefoed K, Dahlman A, Kjær I, Poulsen TT, Meijer PJ, Nielsen LS, Horak ID, Lantto J, Kragh M (2015) Targeting three distinct HER2 domains with a recombinant antibody mixture overcomes trastuzumab resistance. Mol Cancer Ther 14:669-680

34. Yamamoto Y, Iwata H, Ueno T, Taira N, Kashiwaba M, Takahashi M, Tada H, Tsugawa K, Toyama T, Niikura N, Hara F, Fujisawa T, Yoshinami T, Saji S, Takano T, Masuda N, Morita S, Toi M, Ohno $S$ (2018) A randomized, open-label, phase III trial of pertuzumab retreatment in HER2-positive locally advanced/metastatic breast cancer patients previously treated with pertuzumab, trastuzumab and chemotherapy: the Japan Breast Cancer Research Group-M05 PRECIOUS study. Jpn J Clin Oncol 48:855-859

Publisher's Note Springer Nature remains neutral with regard to jurisdictional claims in published maps and institutional affiliations. 